Treatment was started with Benoral Suspension $10 \mathrm{ml}$ twice daily, and steroid treatment was begun two days later at a dose of $30 \mathrm{mg}$ of entericcoated prednisolone daily. Good clinical control of the polyarthropathy enabled the steroid dosage to be reduced to $5 \mathrm{mg}$ twice daily after 10 days, by which time erythrocyte sedimentation rate was $21 \mathrm{~mm}$ in the first hour and the rash had largely cleared. She was discharged taking enteric-coated prednisolone $5 \mathrm{mg}$ twice daily and naproxen $500 \mathrm{mg}$ in the morning with food. Steroids were reduced over the next three months and all medication then stopped; tests for rheumatoid factor remained negative and both the rash and joint symptoms resolved completely.

\section{Comment}

We considered that this was a serum sickness type 3 reaction, probably due to the hair straightener. The straightener was later found to contain a total of 14 compounds, of which either hydrolysed animal protein or protamine nucleic acid complex may have been the precipitating factor in this case. Serum sickness due to hair straightener has not previously been reported, and the consumer safety unit at the Department of Trade, the Health and Safety Commission, and the manufacturers of the product are not aware of any similar cases.

I thank Dr M F Grayson for allowing me to report on one of his patients.

${ }^{1}$ Dickson FJ. The role of antigen-antibody complexes in disease. Harvey Lect 1963;58:21.

${ }^{2}$ Ruddy S, Gigli I, Austen KF. The complement system of man. N Engl 7 Med 1972;287:489-95.

(Accepted 21 October 1981)

Department of Rheumatology and Rehabilitation, North Middlesex Hospital, Edmonton, London N18 1QX

K E KOTOWSKI, MA, MRCP, senior registrar

\section{Mumps virus isolated from a fetus}

A prospective study ${ }^{1}$ confirmed an association between gestational mumps and spontaneous abortion and showed a fetal mortality of $27 \%$ in 33 women who developed mumps in the first trimester of pregnancy, compared with a mortality of $13 \%$ in uninfected mothers. We report the isolation of mumps virus from a fetus spontaneously aborted four days after the mother developed clinical mumps.

\section{Case report}

A 28-year-old woman, gravida 4 para 1, had started her last menstrual period before her fifth pregnancy on 2 May 1981. On 1 August she developed clinical mumps and four days later spontaneously aborted a 10-week fetus. Serum samples taken at an earlier antenatal visit and four weeks later confirmed the clinical diagnosis, the mumps virus complement fixation titres having risen from $<8$ to 256 .

The fetus was examined in the laboratory. Specimens of lung, liver, and brain were pooled and the homogenised suspension inoculated on to tissue cultures for virus isolation. A haemadsorbing virus was detected in primary baboon kidney-cell cultures on the 10th day, and this was shown to be mumps virus by a direct fluorescence antibody technique using a rabbi antimumps serum conjugated with fluorescein. To determine any chromosome abnormalities fibroblast cultures were set up from the fetal material using standard techniques and cultured in Eagles's medium with $20 \%$ fetal calf serum. After 19 days chromosome preparations were made and stained with toluidine blue. Of 50 cells examined, only three showed aberrations: one a chromosome break, one a chromatid break, and one an extra fragment. G-banded preparations showed a normal female karyotype.

\section{Comment}

We believe this to be the first report of isolation of mumps virus from a human fetus. Little direct evidence has previously existed of fetal infection early in pregnancy. No firm evidence associating maternal mumps with prematurity or congenital malformations appears to exist, and the postulated association with endocardial fibroelastosis is still debatable. ${ }^{2}$ Garcia et al, ${ }^{3}$ however, claimed to have found morphological evidence of mumps infection in three placentas and the adrenal cortex of one fetus obtained from mothers whose pregnancies were terminated because they had had mumps in the second or fifth month.

Experimental infection of rhesus monkeys ${ }^{4}$ has shown that mumps virus can cross the placenta. The virus was isolated from fetal tissue for only one week after mothers were infected in the first trimester of pregnancy. The brevity of this period of virus replication in the fetus was thought to be responsible for the lack of mumps antibody in the progeny, who nevertheless showed a delayed hypersensitivity response to intradermal mumps antigen. This "split immunological recognition" has also been observed in man. That mumps virus can cross the placenta late in pregnancy was also suggested by Jones et al, ${ }^{5}$ who isolated the virus at birth from the pharynx of two out of three infants whose mothers had had clinical mumps four to seven days before delivery.

Studies of the chromosomes of the infected fetus reported on above failed to show any abnormalities suggestive of an underlying genetic cause for the fetal death. Although mumps virus may cause changes in lymphocyte chromosomes similar to those caused by measles-that is, chromosome and chromatid breaks and multiple fragmentationthe few cells (three out of 50 ) showing this type of damage were within normal limits for cells grown in tissue culture and do not suggest widespread virally induced chromosome damage. Given the presence of the virus, however, some more localised chromosome damage might possibly have been caused in organs not examined.

This case shows conclusively that transplacental mumps infection occurs.

We thank Mr A Williams for referring this patient.

${ }^{1}$ Siegal M, Fuerst HT, Peress NG. Comparative fetal mortality in maternal virus diseases. $N$ Engl f Med 1966;274:768-71.

2 Hanshaw JB, Dudgeon JA. Virus diseases of the fetus and newborn. Philadelphia: W B Saunders, 1978.

${ }^{3}$ Garcia AG, Pereira JM, Vidigal N, Lobato YY, Pegado CS, Branco JP. Intrauterine infection with mumps virus. Obstet Gynecol 1980;56:756-9.

4 St Geme JW Jr, Peralta H, Van Pelt LF. Intrauterine infection of the rhesus monkey with mumps virus: abbreviated viral replication in the immature fetus as an explanation for split immunologic recognition after birth. F Infect Dis $1972 ; 126: 249-56$.

5 Jones JF, Ray CG, Fulginiti VA. Perinatal mumps infection. 7 Pediatr $1980 ; 96: 912-4$.

(Accepted 28 October 1981)

\section{John Radcliffe Hospital, Headington, Oxford OX3 9DU}

J B KURTZ, MRCP, MRCPATH, consultant virologist, department of virology A H TOMLINSON, DPHIL, FRCPATH, top-grade microbiologist, Public Health Laboratories

J PEARSON, BA, scientific officer, department of medical genetics

\title{
Chest infection caused by Lactobacillus casei ss rhamnosus
}

Association of lactobacilli with human infection has rarely been documented, ${ }^{1}$ although some cases of septicaemia or endocarditis caused by lactobacilli have been reported. ${ }^{2-4}$ Organisms of this genus are generally reported from routine laboratory investigations as "contaminants" or "normal flora" when grown from specimens other than blood. I report a case in which the organism was responsible for chest infection and was isolated from sputum.

\section{Case report}

A 61-year-old woman with chronic myeloid leukaemia was admitted complaining of cough with yellow sputum and difficulty in breathing. On examination chest infection was suspected. She was afebrile and there was no evidence of generalised infection. White cell count on admission was $39 \times 10^{2} / 1$ (neutrophils $32 \times 10^{9} / 1$ ). Oral cephalexin $500 \mathrm{mg}$ six-hourly was prescribed and specimens of sputum and blood taken for culture. Sputum was thick and purulent. Microscopy showed many pus cells and large Gram-positive bacilli. No acid-fast bacilli were present. Culture of sputum produced pure and heavy growth of a diphtheroid organism, which was reported as normal flora. Two days later a second specimen of sputum showed similar microscopic features and produced pure and heavy growth of a diphtheroid as before.

As there was no clinical improvement three days after cephalexin treat- 
ment and no other respiratory organisms were grown we attempted to identify the organism and carried out sensitivity tests. The organism was resistant to penicillin, ampicillin, cephalexin, fusidic acid, and co-trimoxazole, and was sensitive to tetracycline, lincomycin, and gentamicin. Treatment was changed to lincomycin $500 \mathrm{mg}$ by mouth thrice daily. Before this treatment was started a third specimen of sputum and second specimen of blood were obtained for culture. The sputum specimen again grew the same organism, but blood cultures showed no growth after two weeks' incubation. She became clinically well within five days after the changed treatment. The antibiotic was continued for a total of seven days. Two days later a further specimen of sputum was examined. This was not purulent and did not grow the organism or any known respiratory pathogen. She was discharged and was well at follow-up two weeks later.

Bacteriology-Overnight incubation at $37^{\circ} \mathrm{C}$ produced whitish raised colonies of about $0.5 \mathrm{~mm}$ in diameter. Gram-staining showed large nonsporing Gram-positive rods. The organism grew aerobically as well as anaerobically, but slightly better in the presence of carbon dioxide. It was catalase and oxidase negative and non-motile. Similar characteristics were observed in all three cultures. The organism was provisionally named as a Lactobacillus spp and later fully identified by the Central Public Health Laboratory, London, as Lactobacillus casei ss rhamnosus.

\section{Comment}

That this patient's chest infection was caused by a lactobacillus was proved by the following: presence of symptoms and repeated isolation of the same organism from sputum in pure growths; absence of clinical response to cephalexin, to which the organism was insensitive, and clinical and bacteriological cure after treatment with lincomycin, to which the organism was sensitive.

To my knowledge this is the first reported case of a lactobacillus producing chest infection in the absence of septicaemia. Because of their colonial and Gram-staining characteristics lactobacilli are easily mistaken for diphtheroids. Like these, lactobacilli, including the species isolated in this case, may also occur as normal flora in the mouth and gastrointestinal and female genital tracts. The other natural habitats of lactobacilli are milk and milk products. ${ }^{5}$ The clinical importance of isolation of such organisms from non-sterile specimens-for example, sputum-could be established only by repeated isolation in pure growths and by matching clinical cure with negative bacteriology.

1 Sharpe EM, Hill LR, Lapage SP. Pathogenic lactobacilli. f Med Microbiol $1973 ; 6: 281-6$.

2 Tenenbaum MJ, Warner JF. Lactobacillus casei endocarditis. Ann Intern Med $1975 ; 82: 539$.

3 Bayer AS, Chow AW, Betts D, Guze LB. Lactobacillemia-report of nine cases. $A m \mathcal{F}$ Med 1978;64:808-13.

4 Bourne KA, Beebe JL, Lue YA, Ellner PD. Bacteraemia due to Bifidobacterium, Eubacterium or Lactobacillus-twenty one cases. Yale $\mathcal{f}$ Biol Med 1978;51:505-12.

5 In: Wilson GS, Miles A, eds. Lactobacillus and bifidobacterium. Topley and Wilson's principles of bacteriology, virology and immunity. 6th ed. Vol 1. London: Edward Arnold, 1975:956-75.

(Accepted 6 November 1981)

Department of Microbiology, King's Mill Hospital, Sutton-inAshfield, Nottinghamshire

M RAHMAN, MB, MRCPATH, consultant microbiologist

\section{Faecal peritonitis after laxative preparation for barium enema}

The use of purgatives in the routine preparation of the colon is widespread in radiological practice in Britain. ${ }^{1}$ Evaluation of a doublecontrast enema in particular depends on meticulous cleansing of the bowel in order to distinguish small lesions. ${ }^{2}$

We report two cases in which administration of X-Prep (Napp Laboratories Ltd), a concentrated sennoside, was followed by fatal colonic perforation.

\section{Case reports}

\section{CASE 1}

A 71-year-old man had a two-month history of intermittent diarrhoea and rectal bleeding. He was anorexic and had lost $2 \mathrm{~kg}$ in weight over the preced- ing two months but had not complained of abdominal pain. He was referred for outpatient barium enema and was prescribed X-Prep. He took $71 \mathrm{ml}$ $\mathrm{X}$-Prep at $5 \mathrm{pm}$ on the evening before the planned investigation. An initial small bowel movement was followed four hours later by colicky lower abdominal pain, which gradually increased in severity.

He was admitted to hospital the next morning with generalised abdominal tenderness and guarding. At 6 am he developed tachycardia of 120 beats/min, blood pressure fell to $70 / 50 \mathrm{~mm} \mathrm{Hg}$, and he became increasingly dyspnoeic. An erect abdominal radiograph showed free gas under the left diaphragm. $\mathrm{He}$ was resuscitated with intravenous fluids and antibiotics. Laparotomy disclosed faecal peritonitis. Diverticular disease of the descending colon was present but no intraluminal narrowing or identifiable perforation. The abdomen was drained and he was admitted to the intensive therapy unit for intermittent positive-pressure ventilation. He developed acute renal failure and irreversible peripheral ischaemia of the leg and died two days later. Permission for necropsy was refused.

CASE 2

A 65-year-old man had a two-month history of diarrhoea and rectal bleeding. On rectal examination a large tumour was palpable, and he was admitted for urgent investigation and treatment. He received a standard 71 $\mathrm{ml}$ dose of X-Prep on the day before a scheduled barium enema. Later that evening he experienced colicky abdominal pain which initially settled, but at 545 am the next morning he developed generalised abdominal pain with rigidity and rebound tenderness.

At laparotomy he had faecal peritonitis secondary to a $10 \mathrm{~cm}$ tear at the rectosigmoid junction. There was gross intraperitoneal and retroperitoneal soiling. The torn area of colon was resected and the upper portion brought out as an end colostomy. The peritoneal cavity was drained with several polyethylene tube drains. He was admitted to the intensive therapy unit for intermittent positive-pressure ventilation. He required dopamine and later isoprenaline to maintain his blood pressure. Despite initial improvement he died 14 days later of Clostridium welchii septicaemia. At necropsy there was no evidence of spread of the rectal tumour, which did not occlude the rectal lumen.

\section{Comment}

Senna is obtained from an Arabian shrub, and modern preparations can be standardised. X-Prep contains $142 \mathrm{mg}$ sennosides A and B in each $71 \mathrm{ml}$ dose. This is almost six times the maximum recommended daily dose of $24 \mathrm{mg}^{3}{ }^{3}$

Most radiology departments consider X-Prep to be contraindicated in ulcerative colitis, Crohn's disease, and acute diverticulitis because of the risk in subjecting a friable colon to a period of intensive peristalsis. In neither of these cases was there clinical evidence of acute inflammation or obstruction of the colon. When X-Prep is used the development of abdominal pain should raise suspicion of colonic perforation.

No detailed information is available on how many patients in Britain receive X-Prep before a barium enema. In the area of the Greater Glasgow Health Board, which has a population of 990000 , about 12400 barium enemas are performed each year. A total of 10000 patients are given X-Prep before the procedure and are consequently at risk of developing this complication. In addition, several hospitals in the region use the drug before intravenous pyelography.

Perforation of the colon is a recognised complication of barium enema itself ${ }^{4}$ but has only once been reported after the use of X-Prep. ${ }^{5}$ The Committee on Safety of Medicines has had no previous notification of this complication in Britain.

1 Simon G. X-ray diagnosis. 2nd ed. London: Butterworths, 1967:20.

2 Dodds WJ, Scanlon GE, Shaw DK, et al. An evaluation of colon cleansing regimens. AfR 1977;128:57-9.

${ }^{3}$ Martirdale W. The extra pharmacopoeia. 27th ed. Wade A, ed. London: The Pharmaceutical Press, 1977:1343.

4 Seamen WB, Wells J. Complications of the barium enema. Gastroenterology $1965 ; 48: 728-37$.

5 Brovwers JRB, Schneider HS. Bijwerkingen van eenmaal een hoge dosis laxeermiddel. Ned Tydschr Geneeskd 1978;122(30):1098-100.

(Accepted 11 November 1981)

Department of Surgery, Western Infirmary, Glasgow G11 6NT

D GALLOWAY, FRCS, surgical registrar

H J G BURNS, FRCs, lecturer in surgery

L E F MOFFAT, BSC, FRCS, surgical registrar

$S$ G MACPHERSON, FRCS, senior lecturer in surgery 